\title{
Effect of Low Tannin Sorghum Based Feed on Physical and Nutritional Quality of Layer Chicken Eggs
}

\author{
B. A. Ochieng ${ }^{1}$, W. O. Owino ${ }^{1}$, J. N. Kinyuru ${ }^{1}$, J. N. Mburu ${ }^{2}$, M. G. Gicheha ${ }^{2} \&$ L. Kabuage ${ }^{3}$ \\ ${ }^{1}$ Department of Food Science and Technology, Jomo Kenyatta University of Agriculture and Technology \\ (JKUAT), Nairobi, Kenya \\ ${ }^{2}$ Department of Animal Sciences, Jomo Kenyatta University of Agriculture and Technology (JKUAT), Nairobi, \\ Kenya \\ ${ }^{3}$ Department of Agricultural Resource Management, Kenyatta University, Nairobi, Kenya \\ Correspondence: W. O. Owino, Jomo Kenyatta University of Agriculture and Technology Department of Food \\ Science and Technology, P.O Box 62000-00100 Nairobi, Kenya. E-mail: willis@agr.jkuat.ac.ke
}

\begin{tabular}{|c|c|c|}
\hline Received: March 15, 2018 & Accepted: April 20, 2018 & Online Published: May 25, 2018 \\
\hline doi:10.5539/jfr.v7n4p94 & URL: https://doi.org/ & 39/jfr.v7n4p94 \\
\hline
\end{tabular}

\begin{abstract}
This study was carried out to evaluate the effect of replacing maize with low tannin sorghum (LTS) in layer feed on the physical and nutritional quality of eggs of layers at peak egg production stage. One hundred and twenty, 30-weeks old hens were grouped into three blocks of forty birds per block and were subjected to three different diets: $100 \%$ Maize, 50\%Maize 50\%LTS and 100\%LTS for 8 weeks. Eggs were collected on the $4^{\text {th }}$ and $8^{\text {th }}$ week of feeding trial. The results showed that eggs had statistically similar weights, amounts of protein, fat, Vitamin E and Vitamin A. The colour of egg yolks increased in lightness and reduced in hue and Chroma significantly across all the dietary blocks with increase in LTS while cholesterol content decreased. The saturated fatty acid content in the albumin and yolk oil extract remained constant irrespective of the period of feeding or variation of Maize and LTS content. The Monounsaturated fatty acid content decreased significantly $(\mathrm{P}=0.0003)$ during the whole trial diet period. The Polyunsaturated fatty acid content remained constant for the albumin $(\mathrm{P}=0.4095)$ while the yolk showed an increase $(\mathrm{P}=0.1162)$ from the initial $15.82 \pm 0.57 \mathrm{~g} / 100 \mathrm{~g}$ on the $4^{\text {th }}$ week to $24.05 \pm 7.25$ $\mathrm{g} / 100 \mathrm{~g}$ on the $8^{\text {th }}$ week for diets with $100 \%$ Maize. $50 \%$ M50\%LTS increased from $14.59 \pm 0.16$ to $21.48 \pm 4.19$ $\mathrm{g} / 100 \mathrm{~g}$ and $100 \% \mathrm{LTS}$ had its Polyunsaturated fatty acid content decline from $13.36 \pm 0.31$ to $10.71 \pm 0.32 \mathrm{~g} / 100 \mathrm{~g}$. This study indicates that LTS can replace Maize as a source of energy in chicken feeds with no adverse effects on the quality of the eggs.
\end{abstract}

Keywords: albumin, cholesterol, colour, Haugh unit, vitamins, yolk

\section{Introduction}

Feed is an integral part of chicken production enterprise. It is one of the key expenditures in an intensive chicken production system (Narrod, Tiongco, \& Costales, 2012). Energy in feed is an important aspect of the feed quality as it fuels chicken physical and reproductive activities (Bryden et al., 2009). In Kenya maize has been used as the key source of energy in the feed industry. However, maize is a commodity in high demand as it acts as both human food and animal feed ingredient. There is therefore a need to use alternative sources of energy which perform just as well as maize and this can be well achieved by use of LTS grains (Ulrich et al., 2000).

Sorghum is the fifth most popular cereal crop in the world (USDA, 2017). It can grow in arid and semi-arid regions with minimal water, labour and farm input requirement to produce good yield. This makes it suitable for Kenya since the climate is favourable. The problem with high tannin sorghum varieties when used as chicken feed is that they reduce the feed intake, the live weight gain, egg production and size and therefore reduced feed efficiency per dozen of eggs per kg mass (Issa, 2009; Ka \& Mukhtar, 2015). Low Tannin sorghum (LTS) is a variety of sorghum with low tannin content of as low as $1 \%$ which enables it to have minimal deleterious effects when compared to the High tannin sorghum varieties.

In egg production, the productivity of the hens as well as the quality characteristics are of key importance in the consumer acceptability of the eggs(Choi, Park, \& Kim, 2010). The physical quality of the eggs are influenced by the hen breed, housing system, hen age and environmental conditions(Akhtar et al., 2007; Brand, Parmentier, \& 
Kemp, 2004; Mugnai et al., 2016; Parmar et al., 2006). The feed can be used to manipulate some of the quality attributes of the eggs but this is limited as the feed can't perform a versatile role as in meat (Griffin, 1992; Karges \& Corzo, 2010). The protein quality and content of the eggs are highly regulated by the chicken systems and are hard to manipulate based on diets. The saturated fatty acid content of the eggs cannot also be manipulated by the feed ,however, the polyunsaturated fatty acids and the monounsaturated fatty acids are more pliable to be changed by the feed (Meluzzi et al., 2000).

Egg yolk colour is of great importance in the determination of the quality of the yolk as the consumers prefer a deep yellow colour (Beardsworth \& Hernandez, 2004; Jeffrey A. Coutts, 2007). The colour of egg yolk is the most pliable to dietary manipulation as the chicken are not able to synthesize the colouring pigments on their own. The colour is brought about by presence of carotenoids in the chicken diet. LTS has no carotenoids and has detrimental effect on the colour of the egg yolk. It is therefore very important to introduce this component to the layer chicken diets if LTS is to be used in the feed formulation. Preferably use of plant leaves and pure carotenoids like xanthophyll could be exploited for this purpose (Hasin, Ferdaus, Islam, Uddin, \& Islam, 2006; Liu et al., 2012 \& Bonilla et al., 2017).

The objective of this study was to evaluate the effect of feed on the quality of eggs as affected by feed whose source of energy are maize and Low tannin white sorghum in varying quantities.

\section{Methodology}

\subsection{Layer Chicken Feeding and Performance}

The chicken were reared at a commercial poultry farm at Happy Valley Estate, Thika, Kiambu County with geographical coordinates $1.0679^{\circ} \mathrm{S}, 37.1500^{\circ} \mathrm{E}$

One hundred and twenty, thirty-week old, Isa brown layer chicken at peak egg production period feeding on a basal commercial diet were randomly selected and placed into cages/blocks of 40 hens per cage. The chicken were subjected to the trial feed with formulations as shown in Table 1 for 8 weeks. The eggs were collected on the $4^{\text {th }}$ and $8^{\text {th }}$ week of trial for analysis.

Table 1. Feed formulation for layer hens

\begin{tabular}{llll}
\hline Ingredient & Amounts (kg) & & \\
& $100 \%$ Maize Diet 1 (control) & $50 \%$ Maize+ 50\%Sorghum Diet 2 & 100\%Sorghum Diet 3 \\
\hline Maize & 65.0 & 32.5 & - \\
Sorghum & - & 32.5 & 65.0 \\
Soybean meal & 24.5 & 24.5 & 24.5 \\
Vitamin Premix* & 0.25 & 0.25 & 0.25 \\
Iodized salt & 0.25 & 0.25 & 0.25 \\
Methionine & 0.085 & 0.12 & 0.155 \\
Lysine Hcl & 0.05 & 0.05 & 0.05 \\
Bone meal & 2.30 & 2.30 & 2.30 \\
Limestone & 7.50 & 7.50 & 7.50 \\
\hline Total (kg) & 100 & 100 & 100 \\
\hline Calculated nutrient value & & \\
Nutrient & Value & & \\
\hline Metabolisable energy & $235 \mathrm{Kcal} / \mathrm{kg}$ & & \\
Crude protein & $16.5 \%$ & & \\
Calcium & $3.25 \%$ & & \\
Phosphorus & $0.4 \%$ & $0.72 \%$ & \\
Lysine & $0.35 \%$ & & \\
Methionine & & & \\
\hline
\end{tabular}

* Vitamin premix $\left(\mathrm{kg}^{-1}\right)$ : Vitamin A (I.U) 6250000,Vitamin D3 (I.U) 1000000, Vitamin E (I.U) 15000,Vitamin K3 (Mg) 1000, Vitamin B1 (Mg) 500,Vitamin B2 (Mg) 2500, Vitamin B6 (Mg) 2500, Vitamin B12 (Mg) 10, Pantothenic acid (Mg) 600, Nicotinic acid (Mg) 15000, Folic acid (Mg) 500, Biotin (Mg) 35, Choline chloride (Mg) 150000, Iron (Mg) 20000, Copper (Mg) 2500, Zinc (Mg) 25000, Manganese (Mg) 15000, Iodine (Mg) 600, Cobalt (Mg) 400, BHT (Anti-oxidant, Mg) 125000.

The eggs were then transported from the experimental farm in Happy Valley to JKUAT Food Biochemistry Laboratories for physical and chemical analysis. 


\subsubsection{Sample Preparation}

Prior to analysis, twenty eggs from each trial diet were broken and physical characteristics determined before separating the components into albumin and yolk. The samples were stored in the fridge at $0^{\circ} \mathrm{C}$ until analysis.

\subsection{Determination of Proximate Composition}

Proximate composition (moisture, crude protein, and total lipid) of the egg yolk and egg albumin was carried out using the AOAC 2014 method.

\subsection{Determination of Fatty Acid Profile of the Lipid Extracts}

Fatty acid profile was determined according to the procedure described by Almeida et al., (2006). Total lipids were extracted from the albumin and yolk samples using a modified Bligh and Dyer method (1957). After extraction the lipids were methylated using methanolic $\mathrm{HCl}(5 \%)$. The fatty acid methyl esters (FAME) were then determined using Gas Chromatography (Shimadzu GC-14B) equipped with Flame Ionization Detector (FID) and fused capillary column (Omegawax $\left.{ }^{\mathrm{TM}} 5530\right)$ of $30 \mathrm{M} \times 0.53 \mathrm{~mm} \times 0.5 \mu \mathrm{m}$ dimensions. The fatty acids were identified by comparing with the retention times of standards of known methyl esters (Sigma Aldrich 37 components FAME; linoleic acid methyl ester mix (cis/trans); trans-11-vaccenic acid methyl ester; conjugated linoleic acid methyl ester), and the esterified samples. The fatty acids were quantified in $\mathrm{g}$ per $100 \mathrm{~g}$ of the sample.

\subsection{Determination of Cholesterol Content}

This was done using High-Pressure Liquid Chromatography (HPLC) by a method described by Almeida et al. (2006). This method involves two main steps: saponification and cholesterol measurement. Saponification involved the addition of $2 \mathrm{ml}$ of $50 \%$ potassium chloride $50 \%$ potassium hydroxide and $5 \mathrm{ml}$ of $95 \%$ and $5 \%$ ethanol absolute and distilled water respectively to the sample $2 \mathrm{~g}$ of sample. The mixture was heated in a water bath (SHA-C water bath shaker) for complete solubilization at $60{ }^{\circ} \mathrm{C}$ for $10 \mathrm{~min}$. This was followed by an addition of $5 \mathrm{ml}$ distilled ice-cold water and the sample was then cooled in an ice bath. The non-saponifiable fraction was extracted three times using $10 \mathrm{~mL}$ of hexane. Aliquots of hexane extracts $(3 \mathrm{~mL})$ were dried under a vacuum. The extract obtained from saponification was dissolved in $3 \mathrm{~mL}$ of acetonitrile-isopropanol solution $(70: 30, \mathrm{v} / \mathrm{v})$ and analysed with normal phase HPLC using unmodified silica gel as a stationary phase. HPLC apparatus which consisted of a ternary solvent The HPLC apparatus consists of a SHIMADZU® system including a ternary solvent delivery system (LAD 10); a Rheodyne $20 \mathrm{~mL}$ loop injector with column temperature of $30^{\circ} \mathrm{C}$; ultraviolet detector; and software (CLAS-VP 10) for data processing. The mobile phase consisted of acetonitrile and isopropanol (70:30, v/v). Cholesterol identification was done by co-chromatography and by comparing sample retention times with standard retention times (Sigma and Polyscience, U.S.A. ® C8667). Quantification for each sample was achieved by using a standard curve for the standard solutions.

\subsection{Determination of Vitamin E Content}

This was carried out as described by Ponte et al. (2008). Two grams of albumin and yolk samples of each was mixed separately with hexane to dissolve all the vitamin E. The hexane phase was extracted and analysed using HPLC. The HPLC apparatus consists of a SHIMADZU® system including a ternary solvent delivery system (LAD 10); a Rheodyne $20 \mathrm{~mL}$ loop injector with column temperature of $30^{\circ} \mathrm{C}$; ultraviolet detector. The conditions for HPLC were mobile phase consisting of $98 \%$ hexane and $2 \%$ isopropanol, a normal phase column consisting of silica 60 , the oven temperature was set at $25^{\circ} \mathrm{C}$, the flow rate of the mobile phase was 1 to $1.5 \mathrm{ml} /$ minute and the injection volume was $20 \mu 1$.

\subsection{Determination of Vitamin A (retinol) Content}

This was determined as described by Zahar, M., \& Smith, (1990). Briefly, to a 50ml glass stoppered centrifuge tube, $2 \mathrm{~g}$ of sample was added and then $5 \mathrm{ml}$ of absolute ethanol containing $0.1 \%(\mathrm{wt} / \mathrm{vol})$ ascorbic acid followed by $2 \mathrm{ml}$ of $50 \%(\mathrm{wt} / \mathrm{vol}) \mathrm{KOH}$. Centrifuge tubes were closed tightly, agitated carefully and placed in a water bath at $80^{\circ} \mathrm{C}$ for 20 mins. During this period, tubes were agitated periodically to ensure complete digestion of fat. After saponification, the tubes were cooled with running water and then placed in ice water bath $20 \mathrm{mls}$ of hexane containing $0.01 \%$ (weight $/ \mathrm{vol}$ ) BHT was then added. Centrifuge tubes were mixed vigorously with a vortex for $1 \mathrm{~min}$, allowed to stand for 2 minutes and again vortexed for $1 \mathrm{~min}$. $5 \mathrm{mls}$ of cold water $\left(1^{\circ} \mathrm{C}\right)$ was added to each sample and the tubes were inverted 10 times. Centrifugation was done at $1000 \times \mathrm{g}$ for 10 minutes. $10 \mathrm{ml}$ of the upper, organic layer was accurately removed by pipette into a rotary flask and the solvent was evaporated under vacuum at $40^{\circ} \mathrm{C}$ using a rotary evaporator. The residue was immediately dissolved in $1 \mathrm{ml}$ of methanol. The 
samples and the standards were then injected into HPLC, SHIMADZU® system including a ternary solvent delivery system (LAD 10); a Rheodyne $20 \mathrm{~mL}$ loop injector with column temperature of $30^{\circ} \mathrm{C}$; ultraviolet detector, with the following conditions; the mobile phase comprised of $95 \%$ methanol and 5\% distilled water, the flow rate of the mobile phase was $0.8 \mathrm{ml} / \mathrm{min}$, the detector used was the ultra violet detector at $325 \mathrm{~nm}$ wavelength and the injection volume was $20 \mu 1$.

\subsection{Physical Measurements}

\subsubsection{Determination of Haugh unit}

This was determined by the method illustrated by Menezes et al. (2012). The Haugh unit was used to measure protein quality based on height of the egg white. Eggs sampled for each dietary treatment was weighed individually, their widths and lengths measured then broken on a white and smooth surface. The average measurements of albumin height and egg weight was used to compute Haugh unit score for each egg as:

$$
\text { Haugh Unit }=100 \times \log \left(H+7.57-1.7 W^{0.37}\right)
$$

Where: $\mathrm{H}=$ albumen height $(\mathrm{mm})$ and $\mathrm{W}=$ egg weight $(\mathrm{g})$.

\subsubsection{Determination of Yolk Index}

This was done as illustrated by Heiman and Wilhelm, (1937). Yolk height was determined using a tripod micrometre while yolk diameter was measured using steel Vernier callipers. The Yolk index was calculated as:

$$
\text { yolk index }=\left(\frac{\text { yolk height }}{\text { yolk diameter }}\right) \times 100
$$

\subsubsection{Determination of Albumin Index}

This was carried out as illustrated by Rath et al., (2015). After measuring the height and width of albumen of each broken egg, the albumen index was calculated as:

$$
\text { Albumin Index }=\left(\frac{\text { albumin height }(\mathrm{mm})}{\text { albumin length }(\mathrm{mm}) \times \text { albumin width }(\mathrm{mm})}\right) \times 100
$$

\subsubsection{Colour Measurement}

This was carried out using the CIELAB method where the colour values were determined as illustrated by Qiao et al. (2001). The eggs were broken and yolk separated from the albumin. The yolk was put into a transparent glass bottle that was covered using an opaque, black plastic bag and the torch shone for measurement using the CIE Minolta colorimeter. The $\mathrm{L}^{*}, \mathrm{a}^{*}$ and $\mathrm{b}^{*}$ values were recorded for each yolk by taking the colour from three arbitrary places on the glass bottle bottom. The values read were then computed to determine the hue angle and Chroma.

\subsection{Statistical Analysis}

The quantitative data was analysed by STATA/IC 12.0 statistical software in which the evaluation of residual homogeneity was checked using the Shapiro-Wilk test $(\mathrm{p}<0.05)$. Further due to inherent limitations of ANOVA in describing difference in progression of variables over time, the analysis of covariance (ANCOVA) which combines features of both ANOVA and regression was also applied to test effects of diet and age on egg quality, and the interaction effects. When the coefficient of the interaction term was significant $(\mathrm{P}<0.05)$, it was concluded that there was a significant difference between diets and age of hens. One-way ANOVA was performed where treatment outcomes at a specific point in storage time needed to be compared. Means were separated using Bonferroni adjustment at $95 \%$ confidence level.

\section{Results and Discussion}

\subsection{Proximate Composition}

The Table 2 indicate the proximate composition of the albumin and the yolk. The results show that the yolk was generally richer in fat and protein than the albumin. There was no significant $(\mathrm{P}=0.9383)$ difference in the moisture content due to interaction of diet and age in the albumin. There was also no significant difference observed when the main effect was diet $(\mathrm{P}=0.9065)$ or age $(\mathrm{P}=0.9805)$.

Layers fed on diets with higher maize content laid eggs with less variation in protein content ranging between $26.91 \pm 2.81$ to $26.69 \pm 3.51 \%$ against $23.94 \pm 1.20$ to $22.59 \pm 4.19 \%$ for $50 \%$ M50\%LTS and $28.49 \pm 2.40 \%$ to 
$23.34 \pm 1.11 \%$ protein for $100 \%$ LTS. There was no significant difference in relation to interaction between diet and age $(\mathrm{P}=0.9968)$ in the albumin of the eggs and the diets and age had no significant effect independently as their P-values were 0.0925 and 0.6161 respectively. The fat content of the albumin was generally low compared to the yolk with a range of between 0.83 to $4 \%$. There was no significant difference caused by effect of interaction between diet and age $(\mathrm{P}=0.4879)$. Diet had a $\mathrm{P}$-value of 0.5203 while age had a P-value of 0.2444 as the main variables. This shows that the proximate composition of the egg albumin were not affected by the diet or age of the birds as this is an inherent property of the chicken body to regulate these properties.

Table 2. Proximate composition of the eggs

\begin{tabular}{|c|c|c|c|c|c|c|c|}
\hline \multirow[b]{2}{*}{ Period } & \multirow[t]{2}{*}{ Diet } & \multicolumn{3}{|l|}{ Yolk } & \multicolumn{3}{|l|}{ Albumin } \\
\hline & & Fat $(\%)$ & Protein $(\%)$ & Moisture (\%) & Fat $(\%)$ & Protein $(\%)$ & Moisture (\%) \\
\hline \multirow[t]{3}{*}{4 weeks } & 100\% Maize & $3.25 \pm 0.18^{\mathrm{a}}$ & $26.91 \pm 2.81^{\mathrm{a}}$ & $54.78 \pm 0.34^{\mathrm{a}}$ & $0.91 \pm 0.02^{\mathrm{a}}$ & $20.36 \pm 0.95^{\mathrm{a}}$ & $87.34 \pm 0.05^{\mathrm{a}}$ \\
\hline & $50 \%$ M50\%LTS & $8.07 \pm 1.77^{\mathrm{a}}$ & $23.94 \pm 1.20^{\mathrm{a}}$ & $56.56 \pm 1.09^{\mathrm{a}}$ & $1.22 \pm 0.39^{\mathrm{a}}$ & $17.20 \pm 0.95^{\mathrm{a}}$ & $87.08 \pm 0.07^{\mathrm{a}}$ \\
\hline & $100 \%$ LTS & $7.89 \pm 1.46^{\mathrm{a}}$ & $28.49 \pm 2.40^{\mathrm{a}}$ & $55.22 \pm 0.91^{\mathrm{a}}$ & $0.74 \pm 0.06^{\mathrm{a}}$ & $18.71 \pm 1.66^{\mathrm{a}}$ & $87.03 \pm 0.01^{\mathrm{a}}$ \\
\hline \multirow[t]{3}{*}{8 weeks } & $100 \%$ Maize & $21.49 \pm 2.95^{\mathrm{b}}$ & $26.69 \pm 3.51^{\mathrm{a}}$ & $55.64 \pm 1.34^{\mathrm{a}}$ & $0.84 \pm 0.12^{\mathrm{a}}$ & $19.72 \pm 1.80^{\mathrm{a}}$ & $88.13 \pm 0.04^{\mathrm{a}}$ \\
\hline & $50 \% \mathrm{M} 50 \% \mathrm{LTS}$ & $21.04 \pm 2.60^{\mathrm{b}}$ & $22.59 \pm 4.19^{\mathrm{a}}$ & $56.18 \pm 0.61^{\mathrm{a}}$ & $4.00 \pm 1.60^{\mathrm{a}}$ & $16.75 \pm 0.56^{\mathrm{a}}$ & $87.42 \pm 0.05^{\mathrm{a}}$ \\
\hline & $100 \%$ LTS & $6.57 \pm 0.08^{\mathrm{a}}$ & $23.34 \pm 1.11^{\mathrm{a}}$ & $54.75 \pm 0.14^{\mathrm{a}}$ & $1.38 \pm 0.84^{\mathrm{a}}$ & $18.20 \pm 1.22^{\mathrm{a}}$ & $86.04 \pm 2.19^{\mathrm{a}}$ \\
\hline P-Value & $A \& D$ & 0.0006 & 0.6578 & 0.6888 & 0.4879 & 0.9968 & 0.9383 \\
\hline
\end{tabular}

A; age, D; diet

Means with different superscripts on the same column are significantly different $\mathrm{p}<0.05$.

The egg albumin had generally very low fat content of between $0.83 \pm 0.01 \%$ to $4.00 \pm 1.60 \%$, low protein content of between $16.75 \pm 0.56 \%$ to $20.36 \pm 0.95 \%$ and high moisture content of between $86.04 \pm 2.19$ percent to $88.13 \pm 0.04 \%$. This is to signify that the albumin is made up of very high water content and is very lean compared to the yolk. The results from this study gave similar findings as those from previous research work that proved that the protein content and the proximate content of eggs are not altered by dietary interventions as they are very tightly controlled in the avian systems (La et al., 2001; Meluzzi et al., 2000; Milinsk et al., 2003).

Egg yolk had higher fat content ranging between $3.25 \pm 0.18 \%$ to $21.49 \pm 2.95 \%$ across all the ages and diets, this variation was significantly $(\mathrm{P}<0.0001)$ different in relation to interaction between the diets and age of the birds. The protein content of the egg yolks ranged between $20.39 \pm 1.96$ to $28.49 \pm 2.40 \%$. There was no significant $(\mathrm{P}=0.6212)$ difference based on the effect of variation in diet and age of the hen on the protein content. The protein content of the yolk was higher than that of the albumin while the moisture content was lower than that of the yolk with the values ranging between $54.74 \pm 0.43$ to $56.56 \pm 1.09 \%$. There was however no significant $(\mathrm{P}=0.9383)$ difference caused by interaction of both diet and age of the layers on the moisture content of the yolks.

The lack of variability in the proximate components of the egg albumin and egg yolks from chicken fed on various amounts of maize and LTS in the feed of the chicken backs up previous finding that these components are not affected by diets but by other factors including the strain and age of the layers (Minelli et al., 2007).

\subsection{Cholesterol, Vitamin E and Vitamin A Content}

The results in Table 3 show the response of the eggs in relation to the cholesterol, vitamin $\mathrm{E}$ and vitamin A content. The albumin had significantly lower contents of these parameters in comparison to the yolk irrespective of the period from the introduction of the trial diet. There was no significant $(\mathrm{P}=0.7930)$ difference by the effect of the interaction of age and variation of amount of maize and LTS in the diet on the cholesterol content of the egg albumin. Diet alone had no significant $(\mathrm{P}=0.7930)$ effect on the cholesterol content while the age produced a significant difference $(\mathrm{P}=0.035)$ on the cholesterol content. 
Table 3. Cholesterol, Vitamin E and Vitamin A Content

\begin{tabular}{|c|c|c|c|c|c|c|c|}
\hline \multirow[t]{2}{*}{ Period. } & \multirow[b]{2}{*}{ Diet } & \multicolumn{2}{|l|}{ Cholesterol } & \multicolumn{2}{|l|}{ Vitamin E } & \multicolumn{2}{|l|}{ Vitamin A } \\
\hline & & Albumin & Yolk & Albumin & Yolk & Albumin & Yolk \\
\hline \multirow[t]{3}{*}{4 weeks } & $100 \%$ Maize & $167.19 \pm 8.30^{\mathrm{a}}$ & $222.06 \pm 9.97^{\mathrm{a}}$ & $12.07 \pm 1.20^{\mathrm{a}}$ & $21.13 \pm 2.26^{\mathrm{a}}$ & $0.19 \pm 0.13^{b}$ & $0.21 \pm 0.05^{\mathrm{a}}$ \\
\hline & $50 \% \mathrm{M} 50 \% \mathrm{LTS}$ & $156.33 \pm 11.14^{\mathrm{a}}$ & $215.75 \pm 6.52^{\mathrm{a}}$ & $11.03 \pm 1.46^{\mathrm{a}}$ & $18.96 \pm 1.58^{\mathrm{a}}$ & N.D. ${ }^{a}$ & $0.12 \pm 0.01^{\mathrm{a}}$ \\
\hline & $100 \%$ LTS & $162.79 \pm 8.79^{\mathrm{a}}$ & $188.54 \pm 3.29^{\mathrm{a}}$ & $12.23 \pm 2.31^{\mathrm{a}}$ & $18.67 \pm 2.79^{\mathrm{a}}$ & N.D. ${ }^{a}$ & $0.12 \pm 0.01^{\mathrm{a}}$ \\
\hline \multirow[t]{3}{*}{8 weeks } & 100\% Maize & $134.27 \pm 6.06^{\mathrm{a}}$ & $167.54 \pm 12.02^{\mathrm{a}}$ & $11.98 \pm 1.12^{\mathrm{a}}$ & $20.16 \pm 0.85^{\mathrm{a}}$ & $0.14 \pm 0.02^{\mathrm{ab}}$ & $0.29 \pm 0.14^{\mathrm{a}}$ \\
\hline & $50 \%$ M50\%LTS & $154.35 \pm 19.93^{\mathrm{a}}$ & $167.04 \pm 10.76^{\mathrm{a}}$ & $12.09 \pm 1.14^{\mathrm{a}}$ & $18.88 \pm 1.14^{\mathrm{a}}$ & $0.16 \pm 0.02^{\mathrm{ab}}$ & $0.27 \pm 0.12^{\mathrm{a}}$ \\
\hline & $100 \%$ LTS & $132.98 \pm 3.52^{\mathrm{a}}$ & $128.78 \pm 10.85^{\mathrm{a}}$ & $12.48 \pm 0.89^{\mathrm{a}}$ & $18.56 \pm 1.21^{\mathrm{a}}$ & $0.13 \pm 0.01^{\mathrm{ab}}$ & $0.14 \pm 0.03^{\mathrm{a}}$ \\
\hline $\mathrm{P}$-value & $A \& D$ & 0.3307 & 0.8432 & 0.1287 & 0.4562 & 0.1725 & 0.7839 \\
\hline
\end{tabular}

A; age, D; diet

Means with different superscripts on the same column are significantly different by Bonferroni posthoc test $\mathrm{p}<0.05$.

\subsubsection{Cholesterol Content}

Eggs laid by hens fed on $100 \%$ Maize had the highest cholesterol content of $222.06 \pm 9.97 \mathrm{mg} / 100 \mathrm{~g}$ and $167.54 \pm 12.02 \mathrm{mg} / 100 \mathrm{~g}$ for the $4^{\text {th }}$ and $8^{\text {th }}$ week collection respectively in the yolk as compared to the rest of the eggs. The cholesterol content for the other treatments were $162.79 \pm 8.79$ and $156.33 \pm 11.14 \mathrm{mg} / 100 \mathrm{~g}$ for the $50 \%$ M50\%LTS and 100\%LTS respectively. The cholesterol content of the egg yolk differed considerably between the eggs collected on the $4^{\text {th }}$ and $8^{\text {th }}$ week. The egg samples from hens fed on $100 \%$ LTS had the least cholesterol in the yolks. There was a significant $(\mathrm{P}=0.001)$ difference due to interaction between diet and age on the cholesterol content. Diet as the main effect also caused a significant $(\mathrm{P}=0.0041)$ difference on the cholesterol content of the egg yolks. The reports on manipulation of feed studies and reduction cholesterol content concluded that the eggs have 200-250mg/100g of cholesterol (Griffin, 1992 \& Singh, Cheng, \& Silversides, 2009). This agrees with the results found as the egg samples that were analysed had similar amounts of cholesterol.

\subsubsection{Vitamin E Content}

The vitamin E content of the yolks was within a range of between $18.96 \pm 1.21$ to $21.13 \pm 2.26 \mathrm{mg} / 100 \mathrm{~g}$ for both the $4^{\text {th }}$ and $8^{\text {th }}$ week of collection. Samples of eggs collected from hens fed on $100 \%$ Maize had the highest vitamin $\mathrm{E}$ contents of $21.13 \pm 2.26$ and $20.16 \pm 0.85 \mathrm{mg} / 100 \mathrm{~g}$ for $4^{\text {th }}$ and $8^{\text {th }}$ week collection respectively. Maize grains have been cited to have between 0.07 to $0.11 \mathrm{mg} / 100 \mathrm{~g}$ Vitamin E content (Rouf Shah, Prasad, \& Kumar, 2016) while sorghum grains have 0.174 to $0.552 \mathrm{mg} / 100 \mathrm{~g}$ vitamin E content (Afify, El-Beltagi, Abd El-Salam, \& Omran, 2012). The diets had no significant effect on the vitamin E content of both the yolk and the albumin giving P-values of 0.7075 and 0.0677 respectively. Aljamal (2011) reported on the effect of varying the level of vitamin $\mathrm{E}$ in the diet on the egg vitamin $\mathrm{E}$ content. However, this study varied only the source of energy by reducing the amount of maize while increasing the amount of LTS, since maize has considerably higher vitamin E content than sorghum, the lower Vitamin E of the egg albumin and yolk could be explained by this since eggs from chicken fed on pure maize diets had higher vitamin $\mathrm{E}$ content than those with sorghum grains.

\subsubsection{Vitamin A Content}

Vitamin A content of the egg yolks ranged from $0.21 \pm 0.05$ to $0.12 \pm 0.01 \mathrm{mg} / 100 \mathrm{~g}$ on the $4^{\text {th }}$ week of the trial feeding and $0.29 \pm 0.04$ to $0.14 \pm 0.03 \mathrm{mg} / 100 \mathrm{~g}$ on the $8^{\text {th }}$ week. This was a slight increase in the amounts, however, no significant $(\mathrm{P}=0.3215)$ difference was observed on the interaction of variation of diet and age, and no significant $(\mathrm{P}=0.6424)$ difference was also observed on the variation of amount of maize and LTS in the diets. It has been reported that carotenoids are the colouring compounds of egg yolks. Since they are pro-vitamin A forms which are converted to active vitamin A as retinol the values obtained from the colour test combined with the results on vitamin A content reveal that the diets were devoid of this vitamin in its active or inactive form. (Liu et al., 2012; Bonilla et al., 2017). For the albumin there was however a significant $(\mathrm{P}=0.008)$ difference caused by effect of interaction of diet and age on vitamin A content. Diet as the main effect produced no significant $(\mathrm{P}=0.7171)$ difference while age had a significant $(\mathrm{P}=0.0001)$ difference in the yolk retinol content. Albumin samples showed significantly lower vitamin A content as compared to yolks with the values ranging from none detectable to $0.19 \pm 0.13 \mathrm{mg} / 100 \mathrm{~g}$. LTS has considerably low vitamin A content (Bonilla et al., 2017) and this resulted to lower vitamin A content in the albumin and the yolk of the eggs from hens fed on LTS than those of hens fed on $100 \%$ Maize. 
The lower nutrient quality of the albumin in relation to the yolk could be explained by the role of the yolk in embryo formation and growth in the egg before the chick is hatched. The yolk has to have adequate or even extra content of the nutrients to enable the formation of the embryo. It, therefore, has to be richer than the albumin in the nutrient content (Griffin, 1992).

\subsection{Fatty Acid Profile of Egg}

The results in Table 4 show the fatty acid profile of the albumin samples from the different trial diets. There was no significant effect of interaction of age and diet on the palmitic $(\mathrm{P}=0.1304)$, stearic $(\mathrm{P}=0.3908)$, linoleic $(\mathrm{P}=0.7960)$, linolenic $(\mathrm{P}=0.7297)$ acid contents of the albumin. Diets had a significant effect for most of the fatty acids present $(\mathrm{P} \leq 0.05)$.

Table 4. Fatty Acid Profile of Albumin in \% of Lipid Extract

\begin{tabular}{|c|c|c|c|c|c|c|c|}
\hline & \multicolumn{3}{|l|}{4 weeks } & \multicolumn{3}{|l|}{8 weeks } & \multirow{2}{*}{$\begin{array}{l}\text { P-values } \\
\text { A\&D }\end{array}$} \\
\hline & 100\% Maize & $50 \% \mathrm{M} 5 \% \mathrm{LTS}$ & $100 \%$ LTS & 100\% Maize & $50 \%$ M5\%LTS & $100 \%$ LTS & \\
\hline Palmitic (C16:0) & $19.68 \pm 0.50^{\mathrm{a}}$ & $19.42 \pm 0.82^{\mathrm{a}}$ & $20.78 \pm 0.80^{\mathrm{a}}$ & $23.61 \pm 2.08^{\mathrm{a}}$ & $20.69 \pm 0.52^{\mathrm{a}}$ & $26.89 \pm 1.06^{\mathrm{a}}$ & 0.1304 \\
\hline Palmitoleic (C16:1) & $1.21 \pm 0.77^{\mathrm{a}}$ & $0.69 \pm 0.24^{\mathrm{a}}$ & $3.10 \pm 0.16^{\mathrm{b}}$ & $1.58 \pm 0.84^{\mathrm{a}}$ & $1.18 \pm 0.10^{\mathrm{a}}$ & $0.96 \pm 0.13^{\mathrm{a}}$ & 0.0314 \\
\hline Stearic (C18:0) & $7.61 \pm 0.27^{\mathrm{ac}}$ & $6.21 \pm 1.03^{\mathrm{a}}$ & $5.94 \pm 0.23^{\mathrm{a}}$ & $8.74 \pm 0.96^{\mathrm{a}}$ & $9.06 \pm 0.04^{\mathrm{a}}$ & $9.13 \pm 0.06^{\mathrm{a}}$ & 0.3908 \\
\hline Oleic (C18:1) & $14.77 \pm 0.51^{\mathrm{a}}$ & $29.59 \pm 0.08^{\mathrm{b}}$ & $27.08 \pm 1.68^{\mathrm{b}}$ & $21.13 \pm 4.09^{c}$ & $20.51 \pm 0.48^{\mathrm{c}}$ & $27.19 \pm 0.39^{\mathrm{b}}$ & 0.0039 \\
\hline Linoleic (C18:2) & $10.47 \pm 0.24^{\mathrm{a}}$ & $13.88 \pm 0.11^{\mathrm{a}}$ & $15.18 \pm 0.76^{\mathrm{a}}$ & $9.45 \pm 1.92^{\mathrm{a}}$ & $11.70 \pm 0.62^{\mathrm{a}}$ & $13.28 \pm 0.04^{\mathrm{a}}$ & 0.796 \\
\hline Linolenic (C18:3) & $1.51 \pm 0.02^{\mathrm{b}}$ & $0.49 \pm 0.01^{\mathrm{a}}$ & $\mathrm{ND}^{\mathrm{a}}$ & $1.71 \pm 0.77^{\mathrm{a}}$ & $0.30 \pm 0.04^{\mathrm{a}}$ & $0.29 \pm 0.19^{\mathrm{a}}$ & 0.7297 \\
\hline Arachidonic(C20:4) & $1.13 \pm 0.68^{\mathrm{ab}}$ & $4.29 \pm 0.08^{c}$ & $3.29 \pm 0.18^{\mathrm{c}}$ & $0.55 \pm 0.32^{\mathrm{b}}$ & $1.74 \pm 0.25^{\mathrm{a}}$ & $1.96 \pm 0.08^{\mathrm{a}}$ & 0.037 \\
\hline EPA (C20:5) & $1.76 \pm 0.01^{\mathrm{a}}$ & $1.24 \pm 0.00^{\mathrm{a}}$ & $3.94 \pm 0.20^{c}$ & $2.95 \pm 0.32^{\mathrm{b}}$ & $2.59 \pm 0.07^{\mathrm{ab}}$ & $2.28 \pm 0.04^{\mathrm{a}}$ & $<0.0001$ \\
\hline DHA (C22:6) & ND & ND & ND & ND & ND & ND & N/A \\
\hline SFA & $43.13 \pm 1.40^{\mathrm{c}}$ & $32.45 \pm 1.73^{\mathrm{a}}$ & $35.68 \pm 0.44^{\mathrm{ab}}$ & $40.35 \pm 1.85^{\mathrm{bc}}$ & $32.57 \pm 0.29^{\mathrm{a}}$ & $35.78 \pm 3.42^{\mathrm{ab}}$ & 0.0171 \\
\hline MUFA & $17.11 \pm 0.44^{\mathrm{a}}$ & $34.59 \pm 0.07^{\mathrm{b}}$ & $33.48 \pm 2.02^{\mathrm{b}}$ & $23.27 \pm 4.57^{\mathrm{a}}$ & $23.43 \pm 0.33^{\mathrm{a}}$ & $30.83 \pm 0.44^{\mathrm{b}}$ & 0.0044 \\
\hline PUFA & $13.74 \pm 0.26^{\mathrm{a}}$ & $15.63 \pm 0.12^{\mathrm{a}}$ & $19.13 \pm 0.96^{\mathrm{a}}$ & $14.09 \pm 3.01^{\mathrm{a}}$ & $14.59 \pm 0.57^{\mathrm{a}}$ & $15.86 \pm 0.18^{\mathrm{a}}$ & 0.4095 \\
\hline n6/n3 ratio & $6.77 \pm 0.13^{c}$ & $11.56 \pm 0.11^{\mathrm{d}}$ & $3.85 \pm 0.03^{\mathrm{ab}}$ & $3.68 \pm 0.51^{\mathrm{a}}$ & $4.66 \pm 0.39^{c}$ & $5.94 \pm 0.05^{\mathrm{c}}$ & $<0.0001$ \\
\hline
\end{tabular}

A; Age, D; diet.

Means with different superscripts on the same row are significantly different $\mathrm{p}<0.05$.

SFA= saturated fatty acids (C14:0, C15:0, C16:0, C17:0, C18:0, C20:0).

MUFA $=$ monounsaturated fatty acids $(\mathrm{C} 18: 1$ trans-11, C18:1trans-9, C18:1n9c).

PUFA=polyunsaturated fatty acids (C18:2n6c9t12, C18:2n6t9c12, C18:2n6c, C18:3n6, C18:3n3, C18:2n9c11t, C20:2n6, C20:2n6, C20:3n6c, $\mathrm{C} 20: 3 \mathrm{n} 3, \mathrm{C} 20: 4 \mathrm{n} 6, \mathrm{C} 22: 2 \mathrm{n} 6, \mathrm{C} 20: 5 \mathrm{n} 3, \mathrm{C} 22: 5 \mathrm{n}-3, \mathrm{C} 22: 6 \mathrm{n} 3)$.

n-6 (C18:2n6t9t12, C18:2n6c9t12, C18:2n6t9c12, C18:2n6c, C18:3n6, C20:2n6, C20:2n6, C20:3n6c, C20:4n6, C22:2n6).

n-3 (C18:3n3, C20:3n3, C20:5n3, C22:5n-3, C22:6n3).

$\mathrm{ND}=$ Not Detected

The fatty acid profile of the egg albumin showed that the most abundant fatty acid class was the saturated fatty acids followed by the monounsaturated fatty acids and the least concentration was of the polyunsaturated fatty acids. The stearic acid content was very stable irrespective of the diet or period from the introduction of the diets and ranged from $5.94 \pm 0.23 \mathrm{~g} / 100 \mathrm{~g}$ to $9.13 \pm 0.06 \mathrm{~g} / 100 \mathrm{~g}$ of lipid extract. The palmitic acid was the most dominant fatty acid while oleic acid was the most dominant monounsaturated fatty acid. Linoleic acid occurred in more abundance in comparison to the linolenic acid which occurred in low to undetectable quantities. It was also observed that the eicosanoids EPA and DHA occurred in very low quantities while DHA occurred in non-detectable quantities.

The $n 6 / \mathrm{n} 3$ ratio occurred in a range between $3.68 \pm 0.51$ to $11.56 \pm 0.11$. This showed that the lipid quality could be good since it is recommended to be between 6 and 10 for a wholesome nutritional quality (Högberg et al., 2003). Since feeding did not involve modification of the fatty acid profile of the feed, the fatty acid classes responded within a range and this was able to show that the hen systems were able to regulate the fatty acid profile of the eggs they laid. Meluzzi et al. (2000) stipulated that total proteins are not affected by dietary treatments but mineral, fat-soluble vitamins, lipids and fatty acid profile are modified by feed manipulation. However, the saturated fatty acids are almost unresponsive to dietary strategies. This concept was particularly true for the results obtained from this research hence the nutritional quality of chicken egg albumin can conclusively not be easily altered by replacing one component of the feed but by enriching or having a complete overhaul in the nutritional quality of the feed.

Table 5 shows the effect of the feed in relation to the fatty acid profile of the yolks. There was a significant effect 
of interaction of age of hens and diet on most of the fatty acids present in the yolk except for the stearic $(\mathrm{P}=0.5729)$, linoleic $(\mathrm{P}=0.1944)$, arachidonic $(\mathrm{P}=0.6353)$ and $\mathrm{EPA}(\mathrm{P}=0.1389)$ acids of the lipid extracts. Fatty acid profile of the yolk showed that the highest values obtained were from palmitic acid which ranged from $28.71 \pm 0.45 \mathrm{~g} / 100 \mathrm{~g}$ to $31.19 \pm 0.62 \mathrm{~g} / 100 \mathrm{~g}$.

Table 5. Fatty Acid Profile of Yolk in \% of Lipid Extract

\begin{tabular}{llllllll}
\hline & 4 weeks & & & & P weeks \\
& $100 \%$ Maize & $50 \%$ M50\%LTS & $100 \%$ LTS & $100 \%$ Maize & $50 \%$ M50\%LTS & $100 \%$ LTS & A\&D \\
\hline Palmitic (C16:0) & $28.71 \pm 0.45^{\mathrm{a}}$ & $31.19 \pm 0.62^{\mathrm{c}}$ & $30.02 \pm 0.12^{\mathrm{b}}$ & $29.45 \pm 0.14^{\mathrm{ab}}$ & $29.14 \pm 0.35^{\mathrm{ab}}$ & $29.03 \pm 0.33^{\mathrm{ab}}$ & 0.0097 \\
Palmitoleic (C16:1) & $0.34 \pm 0.16^{\mathrm{ab}}$ & $0.09 \pm 0.01^{\mathrm{a}}$ & $0.23 \pm 0.14^{\mathrm{a}}$ & $1.33 \pm 0.00^{\mathrm{c}}$ & $1.60 \pm 0.13^{\mathrm{c}}$ & $0.56 \pm 0.06^{\mathrm{b}}$ & 0.0004 \\
Stearic (C18:0) & $16.3 \pm 0.02^{\mathrm{a}}$ & $15.08 \pm 0.12^{\mathrm{a}}$ & $13.79 \pm 0.26^{\mathrm{a}}$ & $14.01 \pm 2.03^{\mathrm{a}}$ & $11.13 \pm 0.01^{\mathrm{a}}$ & $10.03 \pm 0.01^{\mathrm{a}}$ & 0.5729 \\
Oleic (C18:1) & $25.04 \pm 0.23^{\mathrm{c}}$ & $27.91 \pm 0.05^{\mathrm{cd}}$ & $30.02 \pm 0.04^{\mathrm{d}}$ & $10.23 \pm 0.11^{\mathrm{a}}$ & $15.12 \pm 0.39^{\mathrm{b}}$ & $11.03 \pm 0.01^{\mathrm{a}}$ & $<0.0001$ \\
Linoleic (C18:2) & $13.50 \pm 0.31^{\mathrm{a}}$ & $10.61 \pm 0.08^{\mathrm{a}}$ & $12.85 \pm 0.16^{\mathrm{a}}$ & $21.27 \pm 7.26^{\mathrm{a}}$ & $19.03 \pm 3.82^{\mathrm{a}}$ & $9.69 \pm 0.05^{\mathrm{a}}$ & 0.1944 \\
Linolenic (C18:3) & $0.02 \pm 0.01^{\mathrm{a}}$ & $0.07 \pm 0.01^{\mathrm{a}}$ & $0.14 \pm 0.05^{\mathrm{a}}$ & $0.02 \pm 0.00^{\mathrm{a}}$ & $0.33 \pm 0.11^{\mathrm{b}}$ & $0.004 \pm 0.00^{\mathrm{a}}$ & 0.0059 \\
Arachidonic(C20:4) & $5.91 \pm 0.03^{\mathrm{a}}$ & $3.64 \pm 0.31^{\mathrm{a}}$ & $5.04 \pm 0.01^{\mathrm{a}}$ & $2.05 \pm 1.19^{\mathrm{a}}$ & $0.59 \pm 0.02^{\mathrm{a}}$ & $2.19 \pm 0.57^{\mathrm{a}}$ & 0.6353 \\
EPA (C20:5) & $1.35 \pm 0.22^{\mathrm{a}}$ & $1.95 \pm 0.20^{\mathrm{a}}$ & $1.04 \pm 0.12^{\mathrm{a}}$ & $1.52 \pm 0.01^{\mathrm{a}}$ & $1.36 \pm 0.07^{\mathrm{a}}$ & $0.96 \pm 0.29^{\mathrm{a}}$ & 0.1389 \\
DHA (C22:6) & $0.95 \pm 0.03^{\mathrm{bc}}$ & $0.73 \pm 0.04^{\mathrm{b}}$ & $0.67 \pm 0.08^{\mathrm{b}}$ & $1.24 \pm 0.01^{\mathrm{c}}$ & $0.76 \pm 0.33^{\mathrm{b}}$ & $0.05 \pm 0.00^{\mathrm{a}}$ & 0.0179 \\
SFA & $45.31 \pm 0.39^{\mathrm{a}}$ & $46.78 \pm 0.50^{\mathrm{a}}$ & $44.19 \pm 0.34^{\mathrm{a}}$ & $43.78 \pm 1.94^{\mathrm{a}}$ & $40.60 \pm 0.37^{\mathrm{a}}$ & $39.19 \pm 0.34^{\mathrm{a}}$ & 0.0503 \\
MUFA & $31.28 \pm 0.09^{\mathrm{b}}$ & $31.622 \pm 0.26^{\mathrm{b}}$ & $35.29 \pm 0.12^{\mathrm{c}}$ & $13.62 \pm 1.29^{\mathrm{a}}$ & $17.32 \pm 0.44^{\mathrm{ab}}$ & $13.79 \pm 0.61^{\mathrm{a}}$ & 0.0003 \\
PUFA & $15.82 \pm 0.57^{\mathrm{a}}$ & $13.36 \pm 0.31^{\mathrm{a}}$ & $14.69 \pm 0.16^{\mathrm{a}}$ & $24.05 \pm 7.25^{\mathrm{a}}$ & $21.48 \pm 4.19^{\mathrm{a}}$ & $10.71 \pm 0.32^{\mathrm{a}}$ & 0.1662 \\
n6/n3 ratio & $6.01 \pm 0.52^{\mathrm{a}}$ & $4.09 \pm 0.34^{\mathrm{a}}$ & $7.68 \pm 0.15^{\mathrm{a}}$ & $7.76 \pm 2.67^{\mathrm{a}}$ & $9.11 \pm 0.88^{\mathrm{a}}$ & $11.51 \pm 3.56^{\mathrm{a}}$ & 0.683 \\
\hline
\end{tabular}

A; Age, D; diet.

Means with different superscripts on the same row are significantly different $\mathrm{p}<0.05$.

SFA= saturated fatty acids (C14:0, C15:0, C16:0, C17:0, C18:0, C20:0).

MUFA $=$ monounsaturated fatty acids $(\mathrm{C} 18: 1$ trans-11, C18:1 trans-9, C18:1n9c).

PUFA=polyunsaturated fatty acids $(\mathrm{C} 18: 2 \mathrm{n} 6 \mathrm{c} 9 \mathrm{t} 12, \mathrm{C} 18: 2 \mathrm{n} 6 \mathrm{t} 9 \mathrm{c} 12, \mathrm{C} 18: 2 \mathrm{n} 6 \mathrm{c}, \mathrm{C} 18: 3 \mathrm{n} 6, \mathrm{C} 18: 3 \mathrm{n} 3, \mathrm{C} 18: 2 \mathrm{n} 9 \mathrm{c} 11 \mathrm{t}, \mathrm{C} 20: 2 \mathrm{n} 6, \mathrm{C} 20: 2 \mathrm{n} 6, \mathrm{C} 20: 3 \mathrm{n} 6 \mathrm{c}$, $\mathrm{C} 20: 3 \mathrm{n} 3, \mathrm{C} 20: 4 \mathrm{n} 6, \mathrm{C} 22: 2 \mathrm{n} 6, \mathrm{C} 20: 5 \mathrm{n} 3, \mathrm{C} 22: 5 \mathrm{n}-3, \mathrm{C} 22: 6 \mathrm{n} 3)$.

n-6 (C18:2n6t9t12, C18:2n6c9t12, C18:2n6t9c12, C18:2n6c, C18:3n6, C20:2n6, C20:2n6, C20:3n6c, C20:4n6, C22:2n6).

n-3 (C18:3n3, C20:3n3, C20:5n3, C22:5n-3, C22:6n3).

$\mathrm{ND}=$ Not Detected

The fatty acid content of the eggs collected after 4 weeks of feeding on the trial diet were higher than those obtained after 8 week feeding for most of the attributes as age was shown to have a significant effect as shown in Table 5. The second most abundant fatty acid was oleic acid ranging from $10.23 \pm 0.11$ to $15.12 \pm 0.39 \mathrm{~g} / 100 \mathrm{~g}$ on the $8^{\text {th }}$ week and $25.04 \pm 0.23$ to $30.02 \pm 0.04 \mathrm{~g} / 100 \mathrm{~g}$ on the $4^{\text {th }}$ week. Younger hen eggs had higher levels of oleic acid than eggs produced by older chicken. The third most abundant fatty acid in the yolk lipid extract was linoleic acid which ranged from $9.69 \pm 0.05 \mathrm{~g} / 100 \mathrm{~g}$ to $21.27 \pm 1.26 \mathrm{~g} / 100 \mathrm{~g}$. EPA and DHA were found in very low quantities of between $0.96 \pm 0.2$ to $1.95 \pm 0.20 \mathrm{~g} / 100 \mathrm{~g}$ and $0.05 \pm 0.00$ to $1.24 \pm 0.00 \mathrm{~g} / 100 \mathrm{~g}$ respectively. Diets with $100 \%$ LTS sorghum had the worst performance in relation to the presence of these two eicosanoids.

The most abundant fatty acid group in the yolk was the SFA that was found in a range of between $46.78 \pm 0.50$ $\mathrm{g} / 100 \mathrm{~g}$ to $39.19 \pm 0.34 \mathrm{~g} / 100 \mathrm{~g}$ followed by MUFA at between $13.79 \pm 1.29 \mathrm{~g} / 100 \mathrm{~g}$ to $35.29 \pm 0.12 \mathrm{~g} / 100 \mathrm{~g}$ and the least was the PUFA which was between $10.71 \pm 0.32$ to $24.05 \pm 7.25 \mathrm{~g} / 100 \mathrm{~g}$. These results show that the PUFA regulation was more controlled in all blocks than the MUFA. The n6/n3 ratio ranged from $4.09 \pm 0.34 \mathrm{~g} / 100 \mathrm{~g}$ to $11.5 \pm 3.56 \mathrm{~g} / 100 \mathrm{~g}$ with eggs from hens fed on $100 \% \mathrm{LTS}$ giving higher ratios than $50 \%$ M50\%LTS and 100\%Maize. These results are supported by the work of Meluzzi et al. (2000) who concluded that the Saturated Fatty acid profile of the eggs are very hard to manipulate using dietary interventions. However, the MUFA content and the PUFA content could be altered by dietary intervention. The albumin was more responsive to dietary intervention since 100\% LTS higher MUFA and PUFA content when compared to the yolk. For the yolk the $100 \%$ Maize diet had the highest MUFA and PUFA content for both the $4^{\text {th }}$ and $8^{\text {th }}$ week eggs.

\subsection{Physical Characteristics}

Results in Table 6 show the response of the chicken to the different diet in terms of egg physical characteristic. The layer hens produced heavier eggs on the $8^{\text {th }}$ week compared to on the $4^{\text {th }}$ week. This change was however not significantly different $(\mathrm{P}=0.0910)$. Diet had no significant effect on the weight of the eggs $(\mathrm{P}=0.7918)$, Albumin Index $(\mathrm{P}=0.5112)$, Yolk Index $(\mathrm{P}=0.3115)$ and Haugh Unit $(\mathrm{P}=0.3726)$. 
Table 6. Physical attributes of eggs

\begin{tabular}{|c|c|c|c|c|c|}
\hline Period & Diet & Egg weight $(\mathrm{g})$ & Albumin index & Yolk index & Haugh Unit \\
\hline 4 weeks & 100\% Maize & $50.30 \pm 2.85^{\mathrm{a}}$ & $280.08 \pm 32.50^{\mathrm{a}}$ & $27.65 \pm 0.10^{\mathrm{a}}$ & $55.87 \pm 1.82^{\mathrm{a}}$ \\
\hline \multirow{5}{*}{8 weeks } & $50 \% \mathrm{M} 50 \% \mathrm{LTS}$ & $54.93 \pm 5.12^{\mathrm{a}}$ & $279.17 \pm 32.55^{\mathrm{a}}$ & $30.96 \pm 4.32^{\mathrm{a}}$ & $52.25 \pm 3.64^{\mathrm{a}}$ \\
\hline & $100 \%$ LTS & $53.47 \pm 1.65^{\mathrm{a}}$ & $297.64 \pm 28.61^{\mathrm{a}}$ & $32.13 \pm 1.51^{\mathrm{a}}$ & $56.67 \pm 3.11^{\mathrm{a}}$ \\
\hline & $100 \%$ Maize & $59.12 \pm 0.76^{\mathrm{a}}$ & $336.35 \pm 53.90^{\mathrm{a}}$ & $34.25 \pm 5.73^{\mathrm{a}}$ & $55.42 \pm 7.63^{\mathrm{a}}$ \\
\hline & $50 \% \mathrm{M} 50 \% \mathrm{LTS}$ & $56.02 \pm 2.72^{\mathrm{a}}$ & $397.92 \pm 51.14^{\mathrm{a}}$ & $39.43 \pm 1.67^{\mathrm{a}}$ & $64.13 \pm 2.90^{\mathrm{b}}$ \\
\hline & $100 \%$ LTS & $58.62 \pm 1.20^{\mathrm{a}}$ & $341.95 \pm 24.61^{\mathrm{a}}$ & $34.33 \pm 0.98^{\mathrm{a}}$ & $59.43 \pm 1.49^{\mathrm{a}}$ \\
\hline P-value & $\mathrm{A} \& \mathrm{D}$ & 0.6316 & 0.8209 & 0.7978 & 0.4982 \\
\hline
\end{tabular}

A; age, D; diet

Means with different superscripts on the same column are significantly different $\mathrm{p}<0.05$.

The eggs had a constant weight range of between $50 \mathrm{~g}$ to $60 \mathrm{~g}$ for all the dietary formulations for the 8 week trial period. Eggs from layers fed on $100 \%$ Maize had lower weight of $50.30 \pm 2.85 \mathrm{~g}$ on the $4^{\text {th }}$ week of the feeding trial. However, this changed on the $8^{\text {th }}$ week where they recorded the highest mean weight of $59.12 \pm 0.76 \mathrm{~g}$ compared to the other 2 diets. There was no significant difference $(\mathrm{P}=0.6316)$ caused by interaction of the age of chicken and diet on the weight of the eggs. Egg weight has been reported to be affected by the age of the chicken. Brand et al. (2004), reported a vast variation in age of more than ten weeks can affect the weight of the eggs. This could however not be achieved by the hens in the feeding trial as the age group was the same at the start of the trial and the feeding program lasted for 8 weeks with sample collection being four weeks apart.

There was no significant $(\mathrm{P}=0.8209)$ difference due to interaction of both age of hens and diet on the albumin index. The albumin index of the eggs which is an indicator of egg freshness was very high at the $4^{\text {th }}$ week with a range of between $279.17 \pm 32.55$ to $297.64 \pm 28.61$ and the $8^{\text {th }}$ week ranging between $336.35 \pm 53.90$ to $397.92 \pm 51.14$. The yolk indices ranged between $27.65 \pm 0.10$ to $32.13 \pm 1.51$ for the $4^{\text {th }}$ week while on the $8^{\text {th }}$ week the range was between $34.25 \pm 5.73$ to $39.43 \pm 1.67$. this was however also not significantly different $(\mathrm{P}=0.7978)$. The above results show that the egg samples from chicken fed on $100 \%$ Maize had their physical quality reduce faster since they recorded the lowest values for albumin index and yolk index for both the $4^{\text {th }}$ and $8^{\text {th }}$ weeks of collection.

There was no significant $(\mathrm{P}=0.4982)$ difference caused by interaction of diet and age of hens on the Haugh unit. The diets acting independently as the main variable gave a P-value of 0.138 while the age had a $0.3726 \mathrm{P}$-value. The Haugh unit values ranged from 52.25 \pm 3.64 to $64.13 \pm 2.90$. The Haugh unit is the key factor used in grading of eggs, therefore, the eggs analysed from this feeding trial could be classified as B grade except for the $50 \%$ M50\%LTS on the $8^{\text {th }}$ week which were A grade (USDA, 2000). The Haugh unit is predetermined by the hens at the time they are laid, other factors that influence the Haugh unit of the eggs include flock age, the temperature of storage and the coating of the egg shells before storage(Williams et al., 1992; Scott \& Silversides, 2000). These factors were not taken into consideration in this research but this knowledge could be used to explain the reason for lower Haugh unit at the $8^{\text {th }}$ week compared to the $4^{\text {th }}$ week of collection. The increase in Haugh unit was however very little and there was very little variability observed. Diet has no effect on the Haugh unit, albumin index and yolk index of eggs hence cannot be used to control physical quality of the eggs(Aljamal, 2011; Chung \& Lee, 2014; Doyon, Hamilton, Castaigne, \& Randall, 1985; Lacin, Yildiz, Esenbuga, \& Macit, 2008; Scott \& Silversides, 2000). This was observed to be true in this research study as there was no significant difference due to the variation in LTS and Maize amounts in the diets.

\subsection{Colour}

Results in Table 7 show the colour attributes of the eggs in relation to alterations in amount of maize and LTS in the diets and age of hens. The $\mathrm{L}^{*}$ values were observed to reduce from the $4^{\text {th }}$ week to the $8^{\text {th }}$ week of the dietary feeding trial with a margin of approximately seven units across all the diets. Eggs from hens fed on $100 \%$ Maize as key source of energy recorded the lightest eggs on the $4^{\text {th }}$ week of the feeding trial with $\mathrm{L}^{*}$ values of $68.56 \pm 0.30$ compared to $50 \%$ M50\%LTS and 100\%LTS that had L* values of $65.38 \pm 0.20$ and $66.48 \pm 0.44$ respectively. Diet had a significant effect on the $\mathrm{L}^{*}(\mathrm{P}=0.0418)$ and hue $(\mathrm{P}<0.0001)$ values while the Chroma value was not significantly affected by the variation of level of LTS and maize in the diet $(\mathrm{P}=0.5544)$. this is to imply the exact colour of the yolks were not affected by the variation in diet but the shades and brightness of the yolks were affected by the level of variation of maize with LTS in the chicken feed. 
Table 7. Colour values of egg yolks

\begin{tabular}{|c|c|c|c|c|}
\hline Period & Diet & $\mathrm{L}^{*}$ & Hue & Chroma \\
\hline \multirow[t]{3}{*}{4 weeks } & $100 \%$ Maize & $68.56 \pm 0.30^{c}$ & $36.29 \pm 0.28^{\mathrm{c}}$ & $44.62 \pm 0.15^{\mathrm{d}}$ \\
\hline & $50 \% \mathrm{M} 50 \% \mathrm{LTS}$ & $66.48 \pm 0.44^{\mathrm{b}}$ & $38.95 \pm 0.19^{c}$ & $44.09 \pm 0.21^{\mathrm{d}}$ \\
\hline & $100 \%$ LTS & $65.38 \pm 0.20^{\mathrm{b}}$ & $37.73 \pm 0.28^{\mathrm{c}}$ & $43.04 \pm 0.18^{\mathrm{c}}$ \\
\hline \multirow[t]{3}{*}{8 weeks } & 100\%Maize & $63.63 \pm 1.33^{\mathrm{a}}$ & $-75.07 \pm 0.35^{\mathrm{aA}}$ & $14.76 \pm 0.44^{\mathrm{a}}$ \\
\hline & $50 \% \mathrm{M} 50 \% \mathrm{LTS}$ & $62.96 \pm 0.22^{\mathrm{a}}$ & $-73.99 \pm 0.34^{\mathrm{b}}$ & $16.06 \pm 0.71^{b}$ \\
\hline & $100 \%$ LTS & $61.01 \pm 0.61^{\mathrm{a}}$ & $-74.46 \pm 0.27^{\mathrm{ab}}$ & $16.92 \pm 0.12^{b}$ \\
\hline P-value & $A \& D$ & 0.0033 & 0.0319 & $<0.0001$ \\
\hline
\end{tabular}

A; age, D; diet

Means with different superscripts on the same column are significantly different $\mathrm{p}<0.05$.

The highest L* values were recorded for eggs from hens fed on $100 \%$ Maize while the lowest values were recorded for diets with $100 \%$ LTS. The hue angle ranged from $36.29 \pm 0.28$ to $38.95 \pm 0.19$ on the $4^{\text {th }}$ week while on the $8^{\text {th }}$ week of the trial diet the hue angle of the egg yolks ranged between $-75.07 \pm 0.35$ to $-73.99 \pm 0.34$. The Chroma values ranged from $43.04 \pm 0.18$ to $44.62 \pm 0.15$ on the $4^{\text {th }}$ week of the feeding trial while on the $8^{\text {th }}$ week the range was from $14.76 \pm 0.44$ to $16.92 \pm 0.12$. There was no significant $(\mathrm{P}=0.5544)$ difference due the effect of the variation in levels of LTS and Maize in the diets. This shows that the inclusion of sorghum had no adverse effect on the colour of the yolks. The results obtained showed that all dietary formulations were devoid of elements responsible for colour and the maize samples had higher concentrations of these than the LTS. This is because it has been reported previously that the pigmenting compounds of interest in egg yolk are the $\beta$-carotenes and the $\beta$-cryptoxanthin which are naturally found in leaves and in small quantities in some cereal grains (Liu et al., 2012; Surai, Speake, \& Sparks, 2001; Bonilla et al., 2017).

Low Tannin Sorghum had a negative effect on yolk colour attributes with regards to hue and $\mathrm{L}^{*}$ values. Physical attributes which included egg weights, Albumin Index, Yolk Index and Haugh Unit were not significantly affected by the variation of level of LTS and Maize in the chicken diets. The vitamin E and vitamin A content were lower in eggs of hens fed on higher LTS compared to those of eggs of hens fed on 100\% Maize.

\section{Conclusion}

Low Tannin Sorghum can be used to replace maize in layer chicken feed but the feed formulation has to be enriched using ingredients that are rich in the micronutrients especially pro-vitamin and vitamin A and vitamin E. This will result in higher contents of these in the eggs. Due to the lower content of the cholesterol in the eggs of chicken fed on 100\%LTS, the feed results in more nutritious eggs compared to feed with higher maize content. $100 \%$ LTS can therefore be used to replace $100 \%$ Maize as a source of energy in feed formulations.

\section{Acknowledgement}

This research project was funded by The Regional Universities Forum for Capacity Building in Agriculture (RUFORUM) under Graduate Research Grants System (No. RU 2015 GRG110) to W. O.

\section{References}

Afify, A. E. M. M. R., El-Beltagi, H. S., Abd El-Salam, S. M., \& Omran, A. A. (2012). Biochemical changes in phenols, flavonoids, tannins, vitamin E, $\beta$-carotene and antioxidant activity during soaking of three white sorghum varieties. Asian Pacific Journal of Tropical Biomedicine, 2(3), 203-209. http://doi.org/10.1016/S2221-1691(12)60042-2

Akhtar, N., Mahmood, S., Hassan, M., \& Yasmeen, F. (2007). Comparative Study of Production Potential and Egg Characteristics of Lyallpur Silver Black, Fayoumi and Rhode Island Red Breeds of Poultry. Pakistan Veterinary Journal, 27(4), 184-188.

Aljamal, A. (2011). The Effect of Vitamin E, Selenomethionine and Sodium Selenite Supplementation in Laying Hens. Doctoral dissertation, University of Nebraska. Retrieved from http://digitalcommons.unl.edu/animalscidiss/36?utm_source=digitalcommons.unl.edu $\% 2$ Fanimalscidiss $\% 2$ F36\&utm_medium=PDF\&utm_campaign=PDFCoverPages.

Almeida, J. C. De, Perassolo, M. S., Camargo, J. L., Bragagnolo, N., \& Gross, J. L. (2006). Fatty acid composition and cholesterol content of beef and chicken meat in Southern Brazil. Brazilian Journal of Pharmaceutical Science, 42(1), 100-116. https://doi.org/10.1590/S1516-93322006000100012 
Beardsworth, P., \& Hernandez, J. (2004). Yolk colour-an important egg quality attribute. Int Poult Prod, 12(5), 17-18. Retrieved from http://www.positiveaction.info/pdfs/articles/pp12.5p17.pdf

Bonilla, C. E. V, Rosa, A. P., Londero, A., Giacomini, C. B. S., Orso, C., Fernandes, M. O., ... Bonamigo, D. V. (2017). Effect of broiler breeders fed with corn or sorghum diet and canthaxanthin supplementation on production and reproductive performance. Poultry Science, (February), 1-10. http://doi.org/10.3382/ps/pew442

Brand, H. Van Den, Parmentier, H. K., \& Kemp, B. (2004). Effects of housing system (outdoor vs cages) and age of laying hens on egg characteristics. British Poultry Science, 45(6), 745-752. http://doi.org/10.1080/00071660400014283

Bryden, W., Selle, P., Cadogan, D., Li, X., Muller, N., Jordan, D., ... Hamilton, W. (2009). A review of the nutritive value of sorghum for broilers. A Report for the Rural Industries Research and Development Corporation. 2009b. 68p.[Links], (9). Retrieved from

http://scholar.google.com/scholar?hl=en\&btnG=Search\&q=intitle:A+review+of+the+nutritive+value+of+so rghum+for+broilers\#0

Choi, I. H., Park, W. Y., \& Kim, Y. J. (2010). Effects of dietary garlic powder and alpha-tocopherol supplementation on performance, serum cholesterol levels, and meat quality of chicken. Poultry Science, 89(8), 1724-1731. http://doi.org/10.3382/ps.2009-00052

Chung, S. H., \& Lee, K. (2014). Effect of Hen Age , Storage Duration and Temperature on Egg Quality in Laying Hens, 13(11), 634-636.

Doyon, G., Hamilton, R. M. G., Castaigne, F., \& Randall, C. J. (1985). Egg Quality 2. Albumen Quality of Eggs from Five Commercial Strains of White Leghorn Hens During One Year of Lay 1 â $€^{\mathrm{TM}}$ 2, 9, 63-66.

Griffin, H. D. (1992). Manipulation of egg yolk cholesterol : a physiologist's view. World's Poultry Science Journal, 48(July). https://doi.org/10.1079/WPS19920010

Hasin, B. M., Ferdaus, A. J. M., Islam, M. A., Uddin, M. J., \& Islam, M. S. (2006). Marigold and Orange Skin as Egg Yolk Color Promoting Agents. International Journal of Poultry Science, 5(10), 979-987. https://doi.org/10.3923/ijps.2006.979.987

Heiman, B. V., \& Wilhelm, L. A. (1937). Relationship between Yolk Index, percentage of Firm White and Albumen Index., 54(7), 426-429.

Högberg, A., Pickova, J., Andersson, K., \& Lundström, K. (2003). Fatty acid composition and tocopherol content of muscle in pigs fed organic and conventional feed with different n6/n3 ratios, respectively. Food Chemistry, 80(2), 177-186. http://doi.org/10.1016/S0308-8146(02)00252-2

Issa, S. (2009). Nutritional value of sorghum for poultry feed in West Africa. Retrieved from http://krex.k-state.edu/dspace/handle/2097/2322

Jeffrey A. Coutts, G. C. W. (2007). Optimum egg quality.

Ka, M., \& Mukhtar, M. A. (2015). Comparative Study to Evaluate nutritive value of maize and sorghum(feteria) with or without commercial enzyme ( xylem) in Broiler Diets, 4(5), 2296-2303.

Karges, K., \& Corzo, A. (2010). Effect of dietary inclusion level of distillers dried grains with solubles on layer performance, egg characteristics, and consumer acceptability 1. Journal of Applied Poultry Res., 19, 30-37. http://doi.org/10.3382/japr.2009-00072

La, R., Blas, C. De, Mateos, G. G., Grobas, S., \& Me, J. (2001). Influence of Source and Percentage of Fat Added to Diet on Performance and Fatty Acid Composition of Egg Yolks of Two Strains of Laying Hens. Poultry Science, 80, 1171-1179. https://doi.org/10.1093/ps/80.8.1171

Lacin, E., Yildiz, A., Esenbuga, N., \& Macit, M. (2008). Effects of differences in the initial body weight of groups on laying performance and egg quality parameters of Lohmann laying hens. Czech Journal of Animal Science, 53(11), 466-471. https://doi.org/10.17221/341-CJAS

Liu, Y., Davis, C. R., Schmaelzle, S. T., Rocheford, T., Cook, M. E., \& Tanumihardjo, S. A. (2012). Beta Cryptoxanthin biofortified maize (Zea mays) increases beta cryptoxanthin concentration and enhances the color of chicken egg yolk 1, 2. Poultry Science, 91, 432-438. http://doi.org/10.3382/ps.2011-01719

Meluzzi, A., Sirri, F., Manfreda, G., Tallarico, N., \& Franchini, A. (2000). Effects of Dietary Vitamin E on the Quality of Table Eggs Enriched with n-3 Long-Chain Fatty Acids 1. Poultry Science, 79, 539-545. 
https://doi.org/10.1093/ps/79.4.539

Menezes, P. C., Lima, E. R., Medeiros, J. P., Oliveira, W. N. K., \& Evêncio-Neto, J. (2012). Egg quality of laying hens in different conditions of storage, ages and housing densities. Revista Brasileira de Zootecnia, 41(9), 2064-2069. http://doi.org/10.1590/S1516-35982012000900014

Milinsk, M. C., Murakami, A. E., Gomes, S. T. M., Matsushita, M., \& Souza, N. E. De. (2003). Fatty acid profile of egg yolk lipids from hens fed diets rich in n-3 fatty acids. Food Chemistry, 83, 287-292. http://doi.org/10.1016/S0308-8146(03)00094-3

Minelli, G., Sirri, F., Folegatti, E., Meluzzi, A., \& Franchini, A. (2007). Egg quality traits of laying hens reared in organic and conventional systems. Italian Journal of Animal Science, 6(SUPPL. 1), 728-730. http://doi.org/10.4081/ijas.2007.1s.728

Mugnai, C., Bosco, A. D., Castellini, C., Mugnai, C., Bosco, A. D., Castellini, C., ... Applicata, B. (2016). Effect of rearing system and season on the performance and egg characteristics of Ancona laying hens and season on the performance and egg characteristics of Ancona laying hens. Italian Journal of Animal Science, 8, 175-188. http://doi.org/10.4081/ijas.2009.175

Narrod, C., Tiongco, M., \& Costales, A. (2012). Global poultry sector trends and external drivers of structural change. Fao, 1-28.

Parmar, S. N. S., Thakur, M. S., Tomar, S. S., \& Pillai, P. V. A. (2006). Evaluation of egg quality traits in indigenous Kadaknath breed of poultry. Livestock Research for Rural Development, 18(9).

Ponte, P. I. P., Alves, S. P., Bessa, R. J. B., Ferreira, L. M. A., Gama, L. T., Bras, J. L. A., ... Prates, J. A. M. (2008). Influence of pasture intake on the fatty acid composition, and cholesterol, tocopherols, and tocotrienols content in meat from free-range broilers. Poultry Science, 87(1), 80-88. https://doi.org/10.3382/ps.2007-00148

Qiao, M., Fletcher, D. L., Smith, D. P., \& Northcutt, J. K. (2001). The effect of broiler breast meat color on pH, moisture, water-holding capacity, and emulsification capacity. Poultry Science, 80(5), 676-680. http://doi.org/10.1093/ps/80.5.676

Rath, P. K., Mishra, P. K., Mallick, B. K., \& Behura, N. C. (2015). Evaluation of different egg quality traits and interpretation of their mode of inheritance in White Leghorns. Veterinary World, 8(2231-916), 449-452. http://doi.org/10.14202/vetworld.2015.449-452.

Rouf Shah, T., Prasad, K., \& Kumar, P. (2016). Maize-A potential source of human nutrition and health: A review. Cogent Food \& Agriculture, 2(1), 1-9. http://doi.org/10.1080/23311932.2016.1166995

Scott, T. A., \& Silversides, F. G. (2000). The effect of storage and strain of hen on egg quality. Poultry Science, 79(12), 1725-1729. http://doi.org/10.1093/ps/79.12.1725

Singh, R., Cheng, K. M., \& Silversides, F. G. (2009). Production performance and egg quality of four strains of laying hens kept in conventional cages and floor pens. Poultry Science, 88(2), 256-264. http://doi.org/10.3382/ps.2008-00237

Surai, P. F., Speake, B. K., \& Sparks, N. H. C. (2001). Carotenoids in Avian Nutrition and Embryonic in Plasma Development . and Egg Yolk Availability and Levels Introduction Avian embryo development is associated with a progressive accumulation in certain tissues of lipids which are rich in polyunsaturated fa. Journal of Poultry Science, 38, 1-27. https://doi.org/10.2141/jpsa.38.1

Ulrich Kleih, S Bala Ravi, B Dayakar Rao, B. Y. (2000). Industrial Utilization of sorghum in India.

USDA. (2000). Egg-Grading Manual.

USDA. (2017). World Agricultural Production. Circular Series May 2014, 1-29. http://doi.org/Circular Series WAP 05-17

Williams, K. C., Belyavin, C. G., Bornstein, S., Lipstein, B., Buckley, D. J., Amour, G. S., ... Stadelman, W. J. (1992). Some factors affecting albumen quality with particular reference to Haugh unit score. World's Poultry Science Journal, 48(1), 5-16. http://doi.org/10.1079/WPS19920002

Zahar, M., \& Smith, D. E. (1990). Vitamin A quantification in fluid dairy products: rapid method for vitamin A extraction for high performance liquid chromatography. Journal of Dairy Science, 73(12), 3402-3407. https://doi.org/10.3168/jds.S0022-0302(90)79036-4 


\section{Copyrights}

Copyright for this article is retained by the author(s), with first publication rights granted to the journal.

This is an open-access article distributed under the terms and conditions of the Creative Commons Attribution license (http://creativecommons.org/licenses/by/4.0/). 